\title{
Drivers of Inflation in the Economy of Bahrain
}

\author{
Ibrahem H. Al-Ezzee ${ }^{1}$ \\ ${ }^{1}$ Economics and finance Department, University of Bahrain, Kingdom of Bahrain \\ Correspondence: Ibrahem H. Al-Ezzee, Economics and finance Department, University of Bahrain, Kingdom of \\ Bahrain. E-mail: alezii@yahoo.com
}

Received: December 27, 2015

Accepted: February 14, 2016

Online Published: February 25, 2016

doi:10.5539/ijef.v8n3p178

URL: http://dx.doi.org/10.5539/ijef.v8n3p178

\begin{abstract}
The study tries to recognize the macroeconomic variables responsible for inflation in Bahrain during the period 1980-2010. For this purpose, co-integration test were used in the empirical analysis. Using Augmented Dickey-Fuller (ADF) Phillips Perron (PP) tests, the variables of the study revealed to be integrated of the order one 1(1) at first difference. Cointegration test was used to state the existence or otherwise of a cointegrating vector in the variables. Trace and Maximum Eigen test value point out co-integration at 5\% level of significance pointing to the fact that the variables have a long-run relationship.
\end{abstract}

The paper found that inflation in the short-run is effected by M2, GEXP, and WACPI supporting the long run analysis. The signs of NEER and IR are not as expected. The error correction term is negative and significant at $1 \%$, so the model is stable and supporting the Co-integration results.

The variance decompositions (VDs) approach is used to capture the relative importance of various shocks and their influences on our variable of inflation. The relative variance of inflation is due the exchange rate and interest rate. The results show that shocks to the CPI itself, Nominal Effective Exchange Rate NEER, Nominal Interest Rate NIR, M2, Government Expenditure GEXP, and Consumer Price Index of Main Partners WACPI over all horizons.

Keywords: broad money supply M2, Consumer Price Index (CPI) and Consumer Price Index of Main Partners (WACPI), Government expenditure (GEXP), Nominal Effective Exchange Rate (NEER), and Nominal Interest Rate (NIR)

\section{Introduction}

In general Inflation is a situation of rapid, continuous and unacceptable high rise in the price index in an economy. As a result, the cost of living continually rises. Inflation causes serious distress for all economy's units; consumers, investors, producers and the government. Long run inflation occurs when the quantity of money (money supply) grows at a faster rate than the RGDP. This means that when there is more money than is needed to acclimatize nominal growth in output, consumers and business firms want to purchase more goods and services than can be produced with available resources (labour, capital, etc.) causing an increase in the price level. Over a short Inflation can occur from various shocks in the economy.

The Kingdom of Bahrain was the first Gulf Country to discover crude oil. It is expected that Bahrain's oil reserves will end up within the next 10-15 years. Accordingly, in order to reduce its reliance on oil. The Bahraini government has actively adopted a policy of diversifying and privatizing its economy with in next five years. It was stated that Bahrain's GDP growth is expected to rise steadily from 4.5 percent in 2011 to 5.234 percent in 2015. Today, Bahrain possesses the most diverse economy in the Gulf States and includes financial, aluminum and tourism sectors which accounts for 75 percent of Bahrain's GDP. In 2010, Bahrain's GDP grew 3.955 percent - with a GDP (PPP) of US\$29.663 billion. http://www.economywatch (2011).

Inflation is usually calculated as the percentage change in CPI from one year to the next. The CPI is the average of the prices of the goods and services purchased by typical household.

Average rate of consumer price inflation in the Kingdom of Bahrain is so moderate and it was found at $2.8 \%$ in 2012. The largest weights and the main drivers of inflationary trends in the country were housing and food. As shown in the figure above, Bahrain's CPI recorded stability over the period 1980-2010. The Telegraph (2014) reports were found that "Bahrain's economy experiences similar inflationary pressures due to increase in oil 
prices. The country's inflation is likely to remain the lowest in the Gulf region, with projections of upward pressures in the future period, due to its economic diversification. Contributing to Bahrain's disproportionate susceptibility to inflation which is petroleum-driven is primarily because of the Central Bank policies, where fiscal policy tied to oil revenues and strong inter-relation of the country's economy with the Kingdom of Saudi Arabia”. (Ghassan Ossman, 2014).

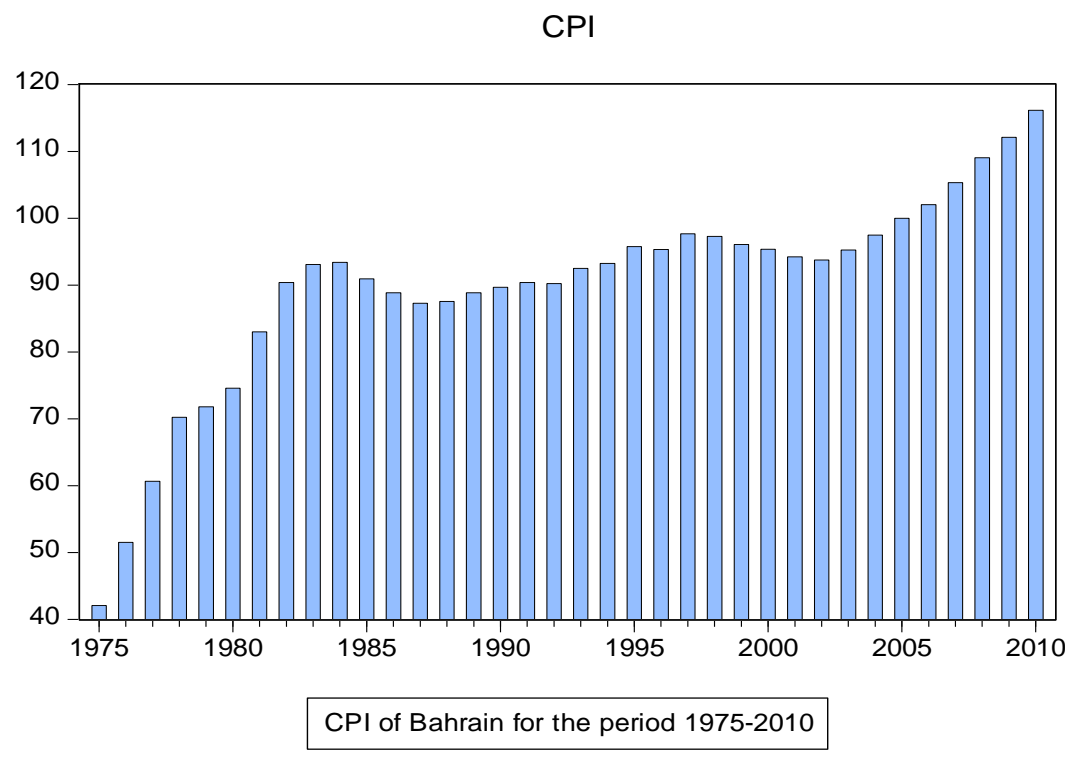

Source: The chart above is generated from actual date using E-Views package.

\section{Methodology}

\subsection{Data and Descriptive Analysis}

The data used in this study is based on annually data which all together investigate the importance of key variables. Data for all the variables used in this paper are obtained from the Word Development Indicators WID and IMF for the period 1975-2010 and Statistical Abstract of Kingdom of Bahrain 1999.

\subsection{Determinations of Inflation}

Analysis of factors causing inflation was discussed extensively over the world. Such influence or factors may be connected to domestic factors such as the level of RGDP, nominal interest, the exchange rate, money supply (Milton Friedman, 1963) and government spending J. M. Keynes (1936) in addition to foreign influences such as consumer price index; Kravis and Lapse (1982); Bhagwati (1984) of the trade partners, and the movements in the nominal effective exchange rate, NEER, Honohan and Lane (2007). Truu (1975), Saini (1982), Adam (1995), Kevin (1998), Moll (1999), Khan and Abdelhak (2001) and Fedderke and Schaling (2005) investigated the relationship between inflation expectations and interest rate variation. As inflation and expected inflation change, nominal interest rate will adjust. The real interest rate corrects the nominal interest rate for the effect of inflation Keynes (1936); Calvo and Végh (1999); Fisher et al. (2000). Therefore, nominal interest rate was considered a driver of inflation rate.

The issue of what drives inflation in small open economies was discussed by Downes et al. (1992), and Cumberbatch (1995). When world prices rise, import and export prices increase as well. It was pointed out by Downes (1985) that the most instrumental variables to the inflationary process are the prime loan interest rate and import. Downes et al. (1991) concluded that "wages, productivity, unemployment and the price of tradable are contributing factors to inflation".

The model of this paper is similar to the model used by Downes et al. (1992). In this model, the main factors influencing the rate of inflation in Bahrain are broad money supply, real effective exchange rate, government spending (expenditure), and consumer price index of main trade partners and nominal interest rate. We specified the following regression model for inflation rate in terms of the CPI dependent variable for the case of Bahrain:

$$
\ln C P I_{t}=\beta_{1}+\beta_{2} \ln M_{2 t}+\beta_{3} \ln N E E R_{t}+\beta_{4} \ln G E X P_{t}+\beta_{5} \ln W A C P I_{t}+\beta_{6} N I R_{t}+U_{t}
$$


The major determinants of inflation in Bahrain are examined by the above econometrics model. The model will include some of fiscal and monetary and foreign policy variables, which are responsible for the price movements. The main purpose of the study is to examine the relationships between inflation and its influences in Bahrain. To examine the short-run and long-run relationship in the models of this study, models or tests such as unit root test, co-integration test and error correction model will be applied.

In regression analysis involving time series data we have to be careful in routinely using the standard classical linear regression assumptions of variables stationary. The concept of stationary time series involves. In general, a stochastic process is said to be stationary if the mean and variance are constant over time and the value of the covariance between two time periods depends only on the distance or lag between the time periods not on the actual time at which the covariance is computed. Gujarati and Porter (2010).

If time series is not stationary, it is called non stationary time series. In this case, regression models involving time series data would gives results that are spurious values, in the sense that primarily the results look good but on further investigation they look suspect. If variables are non-stationary then the slope coefficients would likely have a significant $t$ and high $r^{2}$ despite the independent variable and independent variables are not related, in such situation regression estimators of coefficients are recognized as spurious regression estimates; which mean the results become meaningless. If a time series is not stationary has a unit root (non-stationary), it must be differences $d$ times before it becomes stationary, the first difference of such time series will be stationary. A stationary time series is one who basic properties do not change over time, while a non stationary variable has some sort of upward or downward trend.

\subsection{The Augmented Dickey-Fuller (ADF)}

The ADF model test for a unit auto regressive root tests the null hypothesis $\mathrm{H}_{0}: \delta=0$ against the one sided alternative $\mathrm{H}_{1}: \delta<0$ in the regression.

$$
\Delta y_{t}=\beta_{0}+\delta y_{t-1}+\gamma_{1} \Delta Y_{t-1}+\gamma_{2} \Delta Y_{t-2}+\ldots+\gamma_{p} \Delta Y_{t-p}+u_{t}
$$

Considering null hypothesis $\mathrm{Y}_{\mathrm{T}}$ has a stochastic trend, while under the alternative hypothesis $\mathrm{Y}_{\mathrm{T}}$ is stationary. The ADF statistic is OLS t-statistic testing $\delta=0$ in equation (2). If instead the alternative hypothesis is that $Y_{t}$ is stationary around a deterministic linear time trend, then this is trend, "t" (the observation number) must be added as an additional regressor, in which case the dickey-fuller regression will as follows:

$$
\Delta y_{t}=\beta_{0}+\alpha t+\delta y_{t-1}+\gamma_{1} \Delta Y_{t-1}+\gamma_{2} \Delta Y_{t-2}+\ldots+\gamma_{p} \Delta Y_{t-p}+u_{t}
$$

Where $\alpha$ is constant, $\mathrm{t}$ is a linear time trend, $\beta, \delta$, and $\gamma$ are slope coefficients, $\mathrm{u}_{\mathrm{t}}$ is the error term. (http://www.albany.edu).

\subsection{The Phillips Perron Test}

Other well known unit-root test is the Phillips perron test (Phillips \& Perron, 1988). This test was established to solve the ADF problem of the number of autoregressive lags to be included in the model. The Phillips-Perron test can be computed as the ratio of the OLS of $\rho$, in the simple regression.

$$
\Delta y_{t}=\alpha+\rho \delta t+\rho y_{t-1}+\epsilon_{i t}
$$

Phillips-Perron (PP) test can be used to control the serial correlation when finding the problem of the unit roots. Not as the Augmented Dickey-Fuller (ADF) test, the PP test finds a modified $t$-ratio of $\alpha$ coefficient. The advantage of this test is that the asymptotic distribution of the test statistic is not affected by the serial correlation. These modified statistics are given as follows:

The PP test to find the following statistics:

$$
\tilde{t}_{\alpha}=t_{\alpha}\left(\frac{\gamma_{0}}{f_{0}}\right)^{1 / 2}-\frac{T\left(f_{0}-\gamma_{0}\right)(s e(\tilde{a}))}{2 f_{0}^{1 / 2} s}
$$

Where:

$\hat{\alpha}$ : The estimated coefficient

$t_{\alpha}: t$-ratio of $\alpha$ coefficient

se( $\widehat{\alpha})$ : Coefficient standard error 
$s:$ test regression standard error.

$Y_{0}$ : Estimate of the error variance in the Augmented Dickey-Fuller test*, which is:

$Y_{0}=(T-k) s^{2} / T$

$k$ is the number of regressors.

$f_{0}$ : the estimator of the residual spectrum when the frequency $=0$.

Caution must be taken while performing the PP test. Two paths can be considered when conducting the test:

1) Making the choice to include a constant alone, or a constant coupled with a linear time trend or to include none.

2) How to estimate the $f_{0}$. Eviews can find this estimator based on kernel- based sum of covariances or autoregressive spectral density.

In a multivariate model, one can test for the number of cointegrating relation by using the maximum likelihood methodology of Johansen; the Johansen cointegration test (1988). It is utilized to check the long-run development of the variables. If the variable is differenced once and the differenced is stationary, then it is integrated of order one I(1). If the variable is differenced twice and the differenced series is stationary, then it is integrated of order two I(2), etc. As Engle and Granger (1988) pointed out, just variables with the same order of integration could be tested for co-coordination. Both variables are inspected for their long-run developments by using this test. The test is a standard one and depends on the maximum likelihood estimation of K-dimensional Vector Autoregression (VAR) of order $p$ as follows:

$$
y_{t}=A_{1} y_{t-1}+\ldots+A_{p} y_{t-p}+B x_{t}+\varepsilon_{t}
$$

Where, $y_{t}$ is a $k$-vector of non-stationary I(1) variables, $x_{t}$ is a $d$-vector of deterministic variables (such as a constant, or a constant and time trend etc.) and $\varepsilon_{t}$ is a vector of errors (innovations). This procedure relies on relationships between the rank of a matrix and its characteristic roots or eigenvalues (Johansen, 1988; Johansen \& Juselius, 1990). The Trace (Tr) eigenvalue statistic and Maximum (L-max) eigenvalue statistic is used in this paper. The trace test evaluates the null hypothesis that there is $r$ or less co-integrating vectors against the alternative hypothesis that there is more than $r$. This test is expressed as:

$$
\begin{aligned}
& \lambda_{\text {Trace }}(r)=-T \sum_{i=r+1}^{g} \operatorname{in}\left(1-\hat{\lambda}_{i}\right) \\
& \lambda_{\text {Max }}(r, r+1)=-T \ln \left(1-\hat{\lambda}_{r+1}\right)
\end{aligned}
$$

Where, $\mathrm{T}$ is the number of observations, and the $\lambda_{\mathrm{i}} \mathrm{s}$ are the estimated eigenvalue from the matrix. The maximal eigenvalue test examines the null hypothesis that there are exactly $r$ co-integrating vector against the alternative hypothesis that there is $r+1$ vector. According to Granger (1988), if the variables are integrated of order I(1), then there must be at least one way causation. The maximum likelihood approach produces two sets of coefficients (i) $\beta$, which are the long-run coefficients and (ii) $\alpha$ which are the speeds of adjustment coefficients and roughly equate to the error correction term (ECT). The test for cointegration between the variables is calculated by looking at the rank of the $\pi$ matrix via its eigenvalues. $\pi$ can be defined as the product of two matrices:

$$
\pi=\alpha \beta^{\prime}
$$

If the variables are co-integrated, the existence of an error-correction representation may take the following form:

$$
\begin{aligned}
& \Delta x_{t}=\alpha+\sum_{i=1}^{r} \beta_{i} \Delta x_{t-i}+\sum_{i=1}^{s} \gamma_{j} \Delta y_{t-j}+\delta E C T_{t-1}+u_{t} \\
& \Delta y_{t}=\alpha+\sum_{i=1}^{p} b_{i} \Delta y_{t-i}+\sum_{i=1}^{q} c_{j} \Delta x_{t-j}+d E C T_{t-1}+v_{t}
\end{aligned}
$$

Where, ECT is Error Correction term which is obtained from the co-integration. If the t value of the ECT is negative and significant, the lagged independent variables are important in determining the behaviour of the dependent variable (i.e. CPI of Bahrain). 


\section{The Empirical Results}

\subsection{Augmented Dickey and Fuller Phillips Perron Results}

Time-series regression data sometimes gives results that are spurious. In general, macroeconomic variables have long-term and the variables fluctuate around them. Therefore, spurious problem probably exists mainly in macro econometric models. There are two types of trends seen in the time series data: deterministic and stochastic. The problem is usually with the second type (stochastic trend). If the variable has a stochastic trend (unit root), then the OLS coefficients and there t-statics have no normal distribution. One way of correcting this problem is to take difference of the series successively until stationarity is achieved and then use stationary series for regression analysis.

An investigation of the time series properties of the data using both the Dickey -Fuller Augmented Dickey Fuller (ADF) tests, and Phillips Perron (PP) are used in this paper. The above testing strategy was employed in order to determine the order of integration (or Stationarity). The results of these tests are shown in table (1) and (2).They indicated that the variables of the model have unit roots of I(1). This means that the variables of the model are non-stationary and for this reason may indicate some spurious correlations.

Table 1. Augmented Dickey and Fuller (ADF) results

\begin{tabular}{llll}
\hline \multicolumn{3}{c}{ ADF } \\
\hline Variable & Constant & Const and Trend & No Const. \& No Trend \\
\hline Level & & & \\
LN(CPI) & -0606483 & 1.645090 & 1.539717 \\
LN(M2) & -1.063323 & $-3.640546^{* *}$ & 3.373445 \\
LN(NEER) & -1.943459 & $-5.540820^{*}$ & -0.720971 \\
LN(GEXP) & $-3.107751^{* *}$ & $-4.145799^{* *}$ & 6.004892 \\
LN(WACPI) & 1.549578 & 0.683866 & 2.459880 \\
NIR & 1.948085 & $-4.920992^{*}$ & -1.46300 \\
First Difference & & & \\
LN(CPI) & $-4.916778^{*}$ & $-4.257355^{*}$ & $-4.709477^{*}$ \\
LNM2) & $-9.639407^{*}$ & $-9.633431^{*}$ & $-3.495450^{*}$ \\
LN(NEER) & $-3.385824^{* *}$ & $-3.505340^{* *}$ & $-2.793082^{*}$ \\
LN(GEXP) & $-3.877707^{*}$ & $-3.7068880^{* *}$ & $-2.710358^{*}$ \\
LN(WACPI) & $-7.577259^{*}$ & $-7.308927^{*}$ & $-4.865089^{*}$ \\
NIR & $-4.503822^{*}$ & $-4.637119^{*}$ & $-5.109425^{*}$ \\
\hline
\end{tabular}

Note. In all Tables, $\ln (\mathrm{CPI})$ is the logarithm of consumer price index of Bahrain, $\ln (\mathrm{M} 2)$ is the logarithm of the broad money supply of Bahrain, ln(NEER) is the logarithm of real effective exchange rate for Bahrain, $\ln (\mathrm{GEXP})$ is the logarithm the government expenditure of Bahrain, $\ln$ (WACPI) is the log of average of price index of the main trade partners of Bahrain and NIR is the Nominal interest rate.

Table 2. Phillips Perron (PP) results

\begin{tabular}{llll}
\hline Variable & Constant & Const and Trend & No Const. \& No Trend \\
\hline Level & & & \\
LNCPI) & $-6.043228^{*}$ & $-6.598403^{*}$ & 1.804694 \\
LN(M2) & -1.054204 & $-3.834159^{* *}$ & 3.373445 \\
LN(NEER) & -1.890116 & -2.456736 & -0.833571 \\
LN(GEXP) & -2.399683 & $-3.571248^{* *}$ & 3.806074 \\
LN(WACPI-IMP) & -2.392147 & $-4.788521^{*}$ & 2.589197 \\
NIR & -1.074917 & -3.095722 & -1.314361 \\
first Difference & & & \\
LN(CPI) & $-5.757046^{*}$ & $-4.464402^{*}$ & $-5.186605^{*}$ \\
LN(M2) & $-10.19663^{*}$ & $-10.04719^{*}$ & $-6.707745^{*}$ \\
LN(NEER) & $-3.629639^{*}$ & $-3.534857^{* *}$ & $-3.582485^{*}$ \\
LN(GEXP) & $-3.877707^{*}$ & $-3.076880^{* *}$ & $-2.710358^{*}$ \\
LN(WACPI) & $-6.905233^{*}$ & $-7.308927^{*}$ & $-6.016272^{*}$ \\
NIR & $-6.754396^{*}$ & $-7.326995^{*}$ & $-4.657033^{*}$ \\
\hline
\end{tabular}

Note. ***, **, and* indicate the rejection of null hypothesis of unit root at $1 \%, 5 \%$, and $10 \%$ level of significance, respectively. 


\subsection{VAR and Cointegration Tests}

We have found that all variables under consideration are I(1). We can now carry out cointegration among the variables in the model presented in equation (1) through Johansen and Juselius's (1990) approach. There are two types of tests; the trace and the maximum eigenvalue tests discussed in the Johansen and Juselius's method. The trace tests the null hypothesis state that there is at most $r$ cointegrating relations against the alternative hypothesis of $m$ cointegrating relations where $m$ is the number of endogenous variables. The maximum eigenvalue test null hypothesis is that there are $r$ coinegrating relations against the alternative $r+1$ cointegrating relations. Trace test results are presented in Table 3 and max-eigenvalue test results are presented in Table 4.

Table 3. Cointegration test results-trace statistics

\begin{tabular}{cccc}
\hline Hypothesized & Trace & 0.05 & \\
\hline No. of CE(s) & Statistic & Critical Value & Prob.** \\
None $*$ & 138.7794 & 95.75366 & 0.0000 \\
At most $1 *$ & 83.73164 & 69.81889 & 0.0026 \\
At most $2 *$ & 51.17939 & 47.85613 & 0.0236 \\
At most 3 & 21.25726 & 29.79707 & 0.3418 \\
At most 4 & 8.645821 & 15.49471 & 0.3992 \\
At most 5 & 1.157820 & 3.841466 & 0.2819 \\
\hline
\end{tabular}

Trace test indicates 3 cointegrating eqn(s) at the 0.05 level, $*$ denotes rejection of the hypothesis at the 0.05 level, $* *$ MacKinnon-Haug-Michelis (1999) p-values.

Table 4. Cointegration test results-max. eigenvalue statistics

\begin{tabular}{cccc}
\hline Hypothesized & Max-Eigen & 0.05 & \\
\hline No. of CE(s) & Statistic & Critical Value & Prob.** \\
None $*$ & 55.04780 & 40.07757 & 0.0005 \\
At most 1 & 32.55225 & 33.87687 & 0.0713 \\
At most 2 & 29.92212 & 27.58434 & 0.0246 \\
At most 3 & 12.61144 & 21.13162 & 0.4886 \\
At most 4 & 7.488002 & 14.26460 & 0.4331 \\
At most 5 & 1.157820 & 3.841466 & 0.2819 \\
\hline
\end{tabular}

Max-eigenvalue test indicates 1 cointegrating eiqen(s) at the 0.05 level, * denotes rejection of the hypothesis at the 0.05 level **MacKinnon-Haug-Michelis (1999) p-values.

An intercept and a linear trend are allowed in the cointegrating equations for the results in both Tables 3 and 4 . Trace test indicates two cointegrating equations at the $1 \%$ and $5 \%$ level. We can see from the second column that the first two eigenvalues are much higher compared to the last eigenvalue, which lies near zero. This suggests that there exist two cointegrated relations. The null hypothesis $\mathrm{r}=0$ and $\mathrm{r} \leq 1$ can clearly be rejected. The calculated test value of 138.7794, lies outside the interval between 0 and 95.75366. Also the second test value of 55.04780 is higher than 40.07757, also is the same for third. Max-eigenvalue test indicates no cointegrating relationship, though two cointegration relationships cannot be ruled out altogether about $1 \%$ and $5 \%$ level of significance. Interesting, results in table 4 show that the rejection of null-hypothesis $r=2$ against $r=3$. This nonsensical result is probably due to our small sample applied to Johansen and Juselius's (JJ) method. Based on the above results (and small sample size), it seems that one or two cointegrating relationship exists. Thus, the long-run CPI (ignoring constant and linear trend term) can be written as:

$$
\ln (\mathrm{CPI})=3.841466+0.297141 \ln (\mathrm{M} 2)-0.811387 \ln (\mathrm{NEER})-0.04151 \mathrm{NIR}+0.621 \ln (\mathrm{GEXP})-0.802385 \ln (\mathrm{WACPI})
$$

$$
\begin{array}{llll}
(0.06301) \quad(0.09545) \quad(0.00594) \quad(0.07009)
\end{array}
$$

The signs of all coefficients are as anticipated and came out significant, except WACPI. The co-integrating vector indicates a stationary long-run relationship of CPI with broad money supply (M2), the nominal effective exchange rate (NEER), nominal interest rate (IR), and government expenditure (GEXP). 0.30, - 0.81, -0.04 and 0.62 are the CPI elasticity with respect to M2, NEER, NIR and GEXP respectively. Except 0.04, all other elasticities are reasonably high.

The variables - M2, NEER and NIR - used in the model, affect aggregate demand for goods and services and so 
affect overall prices in the economy in the manner similar to what have been established by Olatunji et al. (2010). Higher responsiveness of CPI comes from NEER in this respect. GEXP and M2 are noted to be the second and third cause of inflation while the weak effect comes from the nominal interest rate. We may conclude from the above results that the CPI of Bahrain is more elastic to nominal effective exchange rate than other variables.

\section{Short Run and Long Run Analysis: An Error Correction Model}

Generally, in most developing countries, such as Bahrain, time series data are usually non-stationary. An econometric model estimation of non stationary data not only violates the main classical regression model assumptions, but also makes policy-making from such econometric results less precise. When the data series show signs of unit roots, the short run dynamic features of the model can be expressed by the error correction model when co-integration exists. Our investigation of the time series properties of the data using the ADF and Phillips Perron (PP) tests has revealed that the variables of the model have unit roots. The variables are integrated of order I(1). This means that the variables of the model are non-stationary and accordingly may show evidence of some spurious results.

\subsection{The Error Correction Model (ECM)}

The error correction model is a logical extension of the cointegration concept. If two variables are cointegrated, then there is an equilibrium relationship connecting them. A regression on these variables therefore is an estimate of this equilibrium relationship along with a residual, which is a measure of the extent to which these variables are out of equilibrium. When formulating a dynamic relationship between the variables, economic theory suggests that the current change in the dependent variable should affected by not only by the current change in the independent variable but also by the extent to which these variables were out of equilibrium in the preceding period: the residual from cointegration process. Studenmund (2011). The resulting equation is the ECM. The co-integration term is known as the error correction term (speed of adjustment) since the deviation from long run equilibrium is corrected gradually through a series of partial short run adjustments. According to Pindyck and Rubinfeld (1991), the existence of at least one Cointegration vector among the variable as showed above, implies that it is appropriate to estimate an ECM. The ECM is useful in the derivation of the short run impacts on the inflation rate in Bahrain. The long-run relationship estimated in equation (2) can be specified as an error correction model as follows:

$$
\Delta L C P I_{t}=\left[\begin{array}{l}
\alpha_{0}+\sum_{j=1}^{q} \beta_{j} \Delta L M 2_{t-j}+\sum_{j=1}^{q} \delta_{j} \Delta L N E E R_{t-j}+\sum_{j=1}^{q} \Phi_{j} \Delta L G E X P_{t-j} \\
+\sum_{j=1}^{q} \varphi_{j} \Delta L W A C P I_{t-j}+\sum_{j=1}^{q} v_{j} \Delta I R_{t-j}+\lambda E C T_{t-1}+\varepsilon_{t}
\end{array}\right]
$$

Where $\Delta$ represents the first difference operator, $\mathrm{EC}_{\mathrm{t}-1}$ the error correction term, and $\mathrm{v}$, a disturbance term. The error correction model utilizes information in the error term of the long-run model to approximate deviations from the equilibrium and represent the short-run response necessary to move the system back toward its equilibrium. The error correction term is calculated as:

$$
E C_{t-1}=P_{t}-P_{t}^{*}
$$

where $\mathrm{Pt}$ is the actual value of $\mathrm{P}$ in period $\mathrm{t}$ and $\mathrm{P}^{*}$ is the fitted value of $\mathrm{P}_{\mathrm{t}}$ estimated in equation (2). The estimated model presented in the following equation:

$$
\Delta L N\left(C P I_{t}\right)=\left[\begin{array}{l}
-0.01911+\sum_{j=1}^{q} 0.0262 \Delta L N\left(M 2^{*}{ }_{t-j}\right)+\sum_{j=1}^{q} 0.007765 \Delta L N\left(N E E R_{t-j}\right)+\sum_{j=1}^{q} 0.4128 \Delta L N\left(G E X P^{* * * * *}{ }_{t-j}\right) \\
+\sum_{j=1}^{q} 0.36136 \Delta L N\left(W A C P I^{* * * * *}{ }_{t-j}\right)+\sum_{j=1}^{q} 0.00444 \Delta N I R^{* * *}{ }_{t-j}-0.0822 E C T^{* * * *}{ }_{t-1}+\varepsilon_{t}
\end{array}\right]
$$

$\mathrm{R}^{2}=0.78$; Adjusted $\mathrm{R}^{2}=0.73$; No. of observation after adjustment $=35 ; \mathrm{D}-\mathrm{W}=1.8$

***, **, and* indicate the rejection of null hypothesis at $1 \%, 5 \%$, and $10 \%$ level of significance, respectively.

All coefficient of the model parameters are significant at $1 \%(*), 5 \%(* *)$ and $10 \%(* * *)$. The signs of M2, GEXP, and WACPI are as expected supporting the long run analysis, but signs of NEER and IR are not. The ECT is negative and significant at $1 \%$, therefore, the model is steady and has the similar to what have been found by the Cointegration results. The important result is the sign and the value of the ECT coefficient. The ECT coefficient of -0.08 mean that it requires about 1 months to eliminate $8 \%$ of the deviation from the long-run equilibrium, after the shock of the M2, GEXP, or WACPI. 


\subsection{Variance Decomposition}

The variance decomposition typically shows the proportion of the forecast error variance of a variable which can be attributed to its own shocks (innovations) and the innovations of the other explanatory variables in the system. It was shown that variance decomposition splits variance of forecast errors for one variable into the contributions of shocks of other variables in vector error correction model, thus stating how important each innovation is in effecting the variables in a vector error correction model (Enders, 1995).

As the lagged variables' effect starts kicking in, the percentage of the effect of other shocks increases over time (See Fortin et al., 2010). To identify orthogonalized innovations in each of the variables and the dynamic responses to such innovations, variance-covariance matrix of the VAR was factorized using Choleski decomposition method suggested by Doan (1989). This method imposes an ordering of the variables in the VAR and attributes all of the effect of any common component to the variable that comes first in the VAR system. The responses can change dramatically if ordering of the variables in the VAR system is changed. We tried several orderings keeping most endogenous variable last and most exogenous first. Cholesky Ordering used here is $\ln (\mathrm{CPI}), \ln (\mathrm{GEXP}), \ln (\mathrm{M} 2), \ln (\mathrm{NEER}), \mathrm{NIR}$, and $\ln (\mathrm{WACPI})$.

Table 5. Variance decomposition of LN(CPI)

\begin{tabular}{cccccccc}
\hline Perid & S.E. & $L N(C P I)$ & $L N(G E X P)$ & $L N(M 2)$ & $L N(N E E R)$ & NIR & $L N(W A C P I)$ \\
\hline 1 & 0.019951 & 100.0000 & 0.000000 & 0.000000 & 0.000000 & 0.000000 & 0.000000 \\
2 & 0.032879 & 86.72672 & 0.511646 & 4.152049 & 3.347622 & 5.260005 & 0.001956 \\
3 & 0.049024 & 62.62295 & 0.526287 & 7.982578 & 11.47039 & 15.53335 & 1.864438 \\
4 & 0.069273 & 45.03543 & 0.554410 & 6.583059 & 26.97666 & 19.17152 & 1.678915 \\
5 & 0.088745 & 36.59362 & 0.579901 & 4.834879 & 38.80090 & 17.86824 & 1.322453 \\
6 & 0.106258 & 31.78993 & 0.405911 & 3.963751 & 46.36294 & 16.43534 & 1.042131 \\
\hline
\end{tabular}

Table 6. Variance decomposition of LN(GEXP)

\begin{tabular}{cccccccc}
\hline Period & S.E. & LN(CPI) & LN(GEXP) & LN(M2) & LN(NEER) & NIR & LN(WACPI) \\
\hline 1 & 0.043449 & 27.40962 & 72.59038 & 0.000000 & 0.000000 & 0.000000 & 0.000000 \\
2 & 0.087573 & 52.28793 & 39.43191 & 6.540943 & 0.045425 & 1.658721 & 0.035067 \\
3 & 0.117858 & 48.39335 & 36.68607 & 8.791859 & 0.311197 & 5.502152 & 0.315379 \\
4 & 0.154718 & 47.75190 & 32.98554 & 9.762750 & 2.483748 & 6.735374 & 0.280684 \\
5 & 0.186379 & 47.98176 & 29.07816 & 9.240967 & 6.059781 & 7.439295 & 0.200028 \\
6 & 0.217079 & 46.72951 & 27.89048 & 8.561201 & 9.319579 & 7.351549 & 0.147683 \\
\hline
\end{tabular}

Table 7. Variance decomposition of LN(M2)

\begin{tabular}{cccccccc}
\hline Period & S.E. & LN(CPI) & LN(GEXP) & LN(M2) & LN(NEER) & NIR & LN(WACPI) \\
\hline 1 & 0.141759 & 17.25990 & 6.039625 & 76.70047 & 0.000000 & 0.000000 & 0.000000 \\
2 & 0.167971 & 13.19799 & 4.303519 & 73.01176 & 0.300376 & 2.381230 & 6.805130 \\
3 & 0.200125 & 11.52226 & 11.67476 & 68.44266 & 1.008358 & 2.469758 & 4.882202 \\
4 & 0.231406 & 14.52244 & 9.142390 & 69.63021 & 0.908053 & 1.864183 & 3.932720 \\
5 & 0.255584 & 12.95632 & 10.14375 & 70.53582 & 0.778705 & 1.893623 & 3.691796 \\
6 & 0.286910 & 15.48399 & 9.483058 & 68.87359 & 0.833232 & 1.853626 & 3.472504 \\
\hline
\end{tabular}

Table 8. Variance decomposition of LN(NEER)

\begin{tabular}{cccccccc}
\hline Period & S.E. & LN(CPI) & LN(GEXP) & LN(M2) & LN(NEER) & NIR & LN(WACPI) \\
\hline 1 & 0.056636 & 3.999559 & 0.318433 & 3.776351 & 91.90566 & 0.000000 & 0.000000 \\
2 & 0.104710 & 2.445460 & 0.151338 & 5.833337 & 88.00227 & 2.493957 & 1.073637 \\
3 & 0.138688 & 3.274042 & 0.575682 & 6.582230 & 83.90397 & 4.087435 & 1.576640 \\
4 & 0.157906 & 3.003295 & 2.787373 & 6.068534 & 82.47632 & 4.217120 & 1.447359 \\
5 & 0.171372 & 2.818523 & 5.659956 & 5.550562 & 80.65370 & 4.044568 & 1.272689 \\
6 & 0.182253 & 2.549627 & 8.475582 & 5.027657 & 78.60172 & 4.176812 & 1.168606 \\
\hline
\end{tabular}


Table 9. Variance decomposition of NIR

\begin{tabular}{cccccccc}
\hline Period & S.E. & LN(CPI) & LN(GEXP) & LN(M2) & LN(NEER) & NIR & LN(WACPI) \\
\hline 1 & 0.969628 & 5.761523 & 0.012877 & 7.116580 & 0.002139 & 87.10688 & 0.000000 \\
2 & 1.494174 & 6.134077 & 5.839302 & 9.287368 & 1.995704 & 72.83868 & 3.904871 \\
3 & 1.766544 & 4.462744 & 14.66938 & 7.558909 & 7.003376 & 61.39856 & 4.907035 \\
4 & 2.105990 & 3.140294 & 16.47032 & 5.430200 & 20.88827 & 48.43895 & 5.631971 \\
5 & 2.434760 & 2.699548 & 15.43026 & 4.134732 & 28.25053 & 44.32055 & 5.164377 \\
6 & 2.672559 & 3.338212 & 13.69448 & 3.646589 & 30.77188 & 43.69267 & 4.856170 \\
\hline
\end{tabular}

Table 10. Variance decomposition of LN(WACPI)

\begin{tabular}{cccccccc}
\hline Period & S.E. & LN(CPI) & LN(GEXP) & LN(M2) & LN(NEER) & NIR & LN(WACPI) \\
\hline 1 & 0.020277 & 2.654757 & 2.507786 & 14.70853 & 3.071772 & 44.84377 & 32.21339 \\
2 & 0.037816 & 3.352616 & 2.139014 & 13.82681 & 9.840109 & 43.58738 & 27.25407 \\
3 & 0.051055 & 2.702180 & 1.434154 & 13.16356 & 17.55013 & 41.25376 & 23.89622 \\
4 & 0.062555 & 2.124252 & 0.995694 & 11.46134 & 26.33664 & 39.05427 & 20.02781 \\
5 & 0.073223 & 1.649727 & 0.795443 & 9.749114 & 33.22608 & 37.13800 & 17.44163 \\
6 & 0.082954 & 1.384053 & 0.911671 & 8.646219 & 37.65373 & 35.50329 & 15.90105 \\
\hline
\end{tabular}

From Table 5, it is possible to describe the relative significance of each structural shock to the variables in the system. We are able to state the variance decomposition of $\ln (\mathrm{CPI})$ over 6 periods ahead. In terms of explaining its own shocks, $100 \%$ of the $\ln (\mathrm{CPI})$ variance can be explained by its own innovation in the first period. This variance partly reflects the impact of variables not included in the model, such as oil prices etc. We also observe that as time goes on; its contributions progressively tumble till it reaches $31.78 \%$ in the last year. However, it still has the highest contribution over the 3 years forecasted compared to the other variables. Thus, it may be concluded that over 3 years ahead, CPI can be highly explained by its own shocks.

Following the CPI itself, the 2nd contribution of the shock of the CPI is $\ln$ (NEER) which contributes $3.347 \%$ in the $2^{\text {nd }}$ year to reach $46 \%$ in the $6^{\text {th }}$ year in explaining the variation of the CPI; this variable becomes prominent in the long-run. The $3^{\text {rd }}$ important shock comes from NIR starting from $5.26 \%$ in the $2^{\text {nd }}$ year to reach it maximum $19.17 \%$ in the $4^{\text {th }}$ year. The lowest shocks of the CPI are noted to be reflected by $\ln (\mathrm{M} 2), \ln (\mathrm{WACPI})$, and $\ln (\mathrm{GEXP})$ respectively.

The statistics indicate the relative contribution of innovations in each of the variables in the system to the variance of the CPI. The results show that shocks to the CPI itself, Nominal Effective Exchange Rate NEER, Nominal Interest Rate NIR, Broad Money Supply M2, Government Expenditure GEXP, and Consumer Price Index of Main Partners WACPI over all horizons.

The statistics and graphs indicate the percentage contribution of innovations in each of the variables in the systems of the variance of inflation. The variance decompositions presented in Table 5 suggest that most of the variance of the forecast errors of the CPI of Bahrain is explained by shocks in itself.

This variance is partly reflecting the impact of the variables such as the exchange rate and interest rate. In the longer horizon, about 32 percent of the variation in the CPI is due to its own shocks. Approximately 63 percent of the variation is accounted by the exchange rate ( 46.7 percent) and interest rate ( 16.4 percent), while only $5 \%$ is due to other influences.

Similarly, Table 6 indicates that 72.5 percent of the variation in the government expenditure is due to its own shocks, while the CPI count (27.5 percent) and the other count small shocks. In the long run about 47 percent of shocks attributed to the variation of CPI and only 28 percent to its self.

From Table 7, while over the six periods about 77 percent of the variation of the first period of the money supply M2 is due to its own shocks, but this effect depreciated to about 69 percent, the rest almost goes to the CPI and GEXP. Table 8 shows that more than 90 percent of variations of nominal exchange rate are due to its own shock, while the rest is attributed to the other factors. The variations in the interest rate are shown in table 9. Most of variation ( 87 percent depreciated to 44 percent in the $6^{\text {th }}$ period) is due the shocks in its self, while rest are mainly due to shocks of nominal interest rate and GEXP. Finally, table 9; indicate that the variation in WACPI is due to shocks of its self and the interest rate. 


\section{Conclusions}

In this paper, we employed various econometric techniques to examine and explain the main determinants of inflation of Bahrain economy both in the long run and in the short run. In this research, the macroeconomic uncertainties that are associated with inflation rate in Bahrain are monetary influences; money supply, interest rate, and exchange rate among others.

Thus, revealing some important facts about the general determinants of inflation in the Nigerian economy. These determinants are multi dimensional and dynamic. Therefore, the government should pursue with vigour, policies that will enhance the reduction of the general price level but enhance increased productivity of goods and services. Such policies may include monetary policy (control money supply), interest rate, and exchange rate among others.

In the long run, the study found that level of CPI depends mainly on monetary variables; broad money supply (M2), the Nominal effective exchange rate (NEER), and nominal interest rate (NIR), and WACPI. Fiscal policy variable as measured by government expenditure (GEXP) is found to be a source of inflation as well. In the short run, inflation is affected by M2, GEXP, and WACPI supporting the long run analysis. The signs of NEER and IR are not as expected. The error correction term is negative and significant at $1 \%$, so the model is stable and supporting the Cointegration results.

Results of variance decomposition indicated that government expenditure shocks are due to the variations of inflation and interest rate. The variance decompositions (VDs) are used to describe the relative importance of various shocks and their influences on inflation. The relative variance of inflation is mainly due the exchange rate and interest rate.

\section{References}

Adam, C. (1995). Fiscal adjustment, financial liberalization, and the dynamics of inflation: Some evidence from Zambia. World Development, 23(5), 35-750. http://dx.doi.org/10.1016/0305-750X(95)00012-2

Ball, R. J., \& Doyle, P. (1969). Inflation: Selected Readings. Harmondsworth, England, Penguin. Penguin Modern Economics Readings.

Bhagwati, J. N. (1984). Why are Services Cheaper in the Poor Countries. The Economic Journal, 374, 279-286. http://dx.doi.org/10.2307/2232350

Branson, W. H., \& Myhrman, J. (1976). Inflation in Open Economies: Supply-Determined versus Demand-Determined Models. European Economic Review, 7(1), 15-34. http://dx.doi.org/10.1016/0014-2921(76)90017-9

Calvo, G., \& Végh, C. (1999). Inflation stabilization and BOP Crisis in Developing countries. In J. Taylor, \& M. Woodford (Eds.), Handbook of Macroeconomics. North Holland.

Cumberbatch, C. A. (1995). A Model of Inflation in Barbados. In D. Worrell, \& R. C. Craigwell (Eds.), Macroeconomics and Finance in the Caribbean: Quantitative Analyses (pp. 109-136). Caribbean Centre for Monetary Studies: St. Augustine: Trinidad and Tobago.

Doan, T., Litterman, R., \& Sims, C. (1984). Forecasting and Conditional Projection using Realistic Prior Distribution. Economic Review, 3, 1-100. http://dx.doi.org/10.1080/07474938408800053

Downes, A. S. (1985). Inflation in Barbados: An Econometric Investigation. Economic Development and Cultural Change, 33(3), 521-532. http://dx.doi.org/10.1086/451477

Downes, A. S., Holder, C., \& Leon, H. L. (1991). A Cointegration Approach to Modelling Inflation in a Small Open Economy. Journal of Economic Development, 16(1), 57-67.

Downes, A. S., Maynard, T., \& Worrell, D. (1992). Macroeconomic Adjustment and the Inflation Experience of Selected Caribbean Countries. Presented at the XXIX Meeting of Technicians of Central Banks of the American Continent.

Enders, W. (1995). Applied econometric time series. New York: Wiley.

Fedderke J. W., \& Schaling, E. (2005). Modelling Inflation In South Africa: A Multivariate Cointegration Analysis. South African Journal of Economics, Economic Society of South Africa, 73(1), 79-92. http://dx.doi.org/10.1111/j.1813-6982.2005.00006.x

Fortin, N., Thomas, L., \& Sergio, F. (2010). Decomposition Methods in Economics. NBER Working Paper No. 16045. 
Friedman, M. (1963). Inflation: Causes and Consequences. New York: Asia Publishing House.

Frisch, H. (1977). Inflation Theory 1963-1975: A Second Generation Survey. Journal of Economic Literature, $15(4), 1289-131$.

Ghassan, O. (2014). Macro Economic Indicators in the Kingdom of Bahrain: Measuring Economic Performance for Global Competitiveness. Proceedings of the First Middle East Conference on Global Business, Economics, Finance and Banking (ME14 DUBAI Conference) Dubai, 10-12 October 2014.

Granger, C. W. J. (1988). Some Recent Developments in a Concept of Causality. Journal of Econometrics 39(1-2), 199-211. http://dx.doi.org/10.1016/0304-4076(88)90045-0

Honohan, P., \& Lane, P. (2007). Divergent inflation rates in EMU. Economic Policy, 357-394.

http://www.albany.edu/ qx668831

http://www.economywatch.com/world_economy/bahrain/economic-forecast.html

Johansen, S. (1988). Statistical Analysis of Cointegrating Vectors. Journal of Economic Dynamics and Control, 12, 231-254. http://dx.doi.org/10.1016/0165-1889(88)90041-3

Johansen, S., \& Juselius, K. (1990). Maximum Likelihood Estimation and Inferences on Cointegration - with applications to the demand for money. Oxford Bulletin of Economics and Statistics, 52, 169-210. http://dx.doi.org/10.1111/j.1468-0084.1990.mp52002003.x

Kevin, R. (1998). Post Stabilization Inflation Dynamics in Slovenia. IMF Working Papers 98/27, International Monetary Fund.

Keynes, J. M. (1936). The General Theory of Employment, Interest and Money. London: Macmillan (reprinted 2007).

Khan, M. S., \& Abdelhak, S. S. (2001). Threshold Effects in the Relationship Between Inflation and Growth. IMF Staff Papers, 48(1), 1.

Kravis, I., \& Lipsey, R. E. (1982). Towards an Explanation of National Price Levels. Princeton Studies in International Finance No. 52, Princeton, NJ: International FinanceCenter, Princeton University, 1983. http://dx.doi.org/10.3386/w1034

Moll, P. G. (1999). Money, Interest Rates, Income and Inflation in South Africa. Wiley-Blackwell, 67(1), 34-64. http://dx.doi.org/10.1111/j.1813-6982.1999.tb01132.x

Olatunji, G. B., Omotesho, O. A., Ayinde, O. E., \& Ayindo, K. (2010). Determinants of Inflation in Nigeria: A Co-integration approach. Paper presented at the Joint $3^{\text {rd }}$ African association of agricultural economists, pp. $1-12$.

Phillips, P., \& Perron, P. (1988). Testing for a Unit Root in Time Series Regression. Biometrica, 75, 335-346. http://dx.doi.org/10.1093/biomet/75.2.335

Pindyck, R. S., \& Rubinfeld, D. L. (1991). Econometric Models \& Economic Forecasts (3rd ed.). McGraw-Hill, International Editions.

Saini, K. G. (1982). The monetarist explanation of inflation: The experience of six Asian countries. South African Journal of Economics, Economic Society of South Africa, 67(1), 15-30. http://dx.doi.org/10.1016/0305-750x(82)90062-6

Studenmund, A. H. (2011). Using Econometrics (6th ed.). Pearson.

Truu, M. L. (1975). Inflation in the South African Economy. South African Journal of Economics, Economic Society of South Africa, 43(4), 272-286. http://dx.doi.org/10.1111/j.1813-6982.1975.tb00458.x

\section{Copyrights}

Copyright for this article is retained by the author(s), with first publication rights granted to the journal.

This is an open-access article distributed under the terms and conditions of the Creative Commons Attribution license (http://creativecommons.org/licenses/by/3.0/). 